\title{
Reflexivity and Rapprochement: \\ Explorations of a 'Postsecular' Public Theology
}

\author{
Elaine Graham \\ University of Chester, UK
}

\begin{abstract}
Accounts of secularization, decline and marginalization in relation to the public position of religion in Western society have failed to account for the continued vitality and relevance of religion in the global public square. It is important, however, to challenge simplistic accounts and think of the new visibility of religion (not least in Europe) in terms of complexity and multi-dimensionality. This article will ask how public theology might contribute constructively to repairing our fractured body politic and promoting new models of citizenship and civic engagement around visions of the common good.
\end{abstract}

\section{Key words}

Postsecular, public theology, secularization, Jürgen Habermas, rapprochement

\section{Introduction}

In this paper, I will argue that recent signs of the resurgence of public religion not only confound much received wisdom about the fate of religion in Western society, but present new and unprecedented challenges at the levels of theory, policy and practice. ${ }^{1}$ I begin from the conundrum that has beset the study of religion and public policy for the past two decades: how, given all predictions regarding the ultimate

\footnotetext{
${ }^{1}$ See Adam Dinham and Mathew Francis, eds, Religious Literacy in Policy and Practice (Bristol: Policy Press,
} 2015). 
demise of religion, has religious belief and practice made such a dramatic return to the public stage? Accounts of secularization, decline and marginalization in relation to the public position of religion in Western society have failed to account for the continued vitality and relevance of religion in the global public square. And yet in part because of such a theoretical mindset around the inevitable decline of religion and the victory of the secular, we must now reckon for its continued existence alongside, and in opposition to, political philosophies that resist its incursion into what is still considered a neutral, secular public sphere. We find ourselves confronted by new waves of religious faith that in their novel and unexpected qualities pose considerable new challenges for the way we think, legislate and behave in relation to religion.

Like others, I have chosen to characterize this context as one of 'post-secular' society $^{2}$ and I will explain in more detail the specific challenges and complexities that come with that. Overall, what it does is to challenge simplistic accounts and to think of the new visibility of religion (not least in Europe) in terms of complexity and multidimensionality.

There are a number of aspects to this. Firstly, there is the way in which religious organizations mobilize networks of activism and association that are simultaneously local, national and international. Secondly, there is the capacity of faith-based activism to combine the 'what' of the resources of social, economic and human capital with the 'why' of beliefs, ethics and attitudes. Thirdly, we are confronted by the often paradoxical and agonistic dimensions of the post-secular age, in which the renewed visibility and currency of faith-based social action continues to be challenged by secularist voices that question the very legitimacy of religious

\footnotetext{
${ }^{2}$ Elaine Graham, Between a Rock and a Hard Place: public theology in a post-secular age (London: SCM Press, 2013).
} 
interventions in the public square.

In addressing how public policy might deal with such impasses, I will consider how these dimensions represent ambivalent legacies. The transnational scope of religion yields significant sensibilities of internationalism but generates divided loyalties in many citizens, thereby undermining national sovereignty. Despite calls to incorporate religious reasoning into public debate, there is little consensus on how that might be reached peaceably and democratically. And finally, the rise of religious identity as a mark of cultural difference renders existing conventions of equality and diversity legislation more problematic. Whilst I have no ultimate solutions, I will argue for policies and practices which (1) foster greater reflexivity on the part of citizensthrough, for example, programmes of religious literacy—and which (2) pay attention to the ways in which broad-based local collaborations can foster forms of postsecular rapprochement-such that religious values are tested and mediated through the promotion of the common good. Reflexivity and rapprochement become watchwords of renewed post-secular civic practices.

\section{The 'Death of God' and other Rumours}

So, is God dead or have rumours of his or her demise been exaggerated? For most of the second half of the twentieth century, the gradual marginalization of religious belief and institutions and the privatization of religious belief and practice formed the mainstay of social scientific thinking about religion. Generations of scholars and public institutions in the West believed that religion was in terminal decline and that gradually it would migrate to the margins of public life before disappearing altogether. The trajectory leading humanity from the religious to the secular seemed somehow inbuilt to the process of history. The decline of religion was inevitable and 
irreversible-indeed desirable, as any incursion of religion into public life represented a diminishment of our human freedom, and was incompatible with modern values of science, reason, enlightenment and progress.

But that's not what's happened. From the last quarter of the twentieth century the world began to see the unexpected 're-enchantment' ${ }^{3}$ of global politics-something we can probably date from the Iranian revolution in 1979, the rise of the Moral Majority in the US in the 1980s, the emergence of Islamist movements in the Middle East, Africa and South Asia. Clearly, the destruction of the World Trade Center on 11 September 2001 stands as an iconic and devastating moment in all this, as an explicitly-religiously motivated intervention in world affairs.

Globally, of course, the rise of radical Islam, especially in the Middle East, East Asia and Africa, and of Hindu nationalism in India, represent examples of the ways in which, far from receding to the margins of our political consciousness, religion has now erupted with unprecedented force. Over the past two years many European cities have been faced with shocking examples of what happens when religion erupts into public life and onto our streets, public buildings and our news media.

In early January 2015 the people of Paris were reeling from the attacks on Charlie Hebdo magazine. As a publication, Charlie Hebdo was known for its uncompromising, often scurrilous, criticism of religious extremism and the abuses of power committed by organized religion. This incident was supposedly a reprisal for its controversial, some felt offensive, portrayal of Islam. Then in November there were attacks on the Bataclan theatre and other venues. Since the beginning of 2016, there have been further incidents in Istanbul, Brussels and Ansbach, as well as (much less widely reported) violence in Burkina Faso, Jakarta and Istanbul, apparently as the

\footnotetext{
${ }^{3}$ After Max Weber who coined the phrase 'the disenchantment of the world' (German 'Entzauberung der Welt') to denote the gradual displacement of tradition, magic and transcendence by the modernizing forces of bureaucracy, technical rationality and scientific enquiry associated with processes of secularization.
} 
result of actions by insurgents from Daesh, or the Islamic State of Iraq and Syria (ISIS).

On another level altogether, but nevertheless quite telling, I think, was the media storm over the summer of 2016 about the wearing of the so-called 'burkini' on certain beaches in the south of France. The burkini, a conflation of 'burqa' (or 'burkha') and 'bikini', and denoting a form of swimwear for (mainly Muslim) women which is seen as conforming to certain religious standards of modesty, became the subject of legal and cultural debate when media images were circulated of police officers requiring women to remove their clothing, and legal battles over whether it was constitutional under French law to prohibit such beachwear. ${ }^{4}$

Within Europe, however, where institutional Christian (but not other religions') decline appears to be a verification of some aspects of twentieth century secularization theory, religion is reasserting its visibility within the political discourses shaping fundamental debates about the social order, as well as colonizing new spaces and generating new alliances and social movements. Ironically, cuts in government funding since the economic crisis of 2008-9 have furnished the churches with opportunities to 'push back against the pressures of secularization' 5 by offering buildings, resources and volunteers as statutory facilities are withdrawn. There are other dimensions to this new visibility: evidence consistently reports that those who participate in religious activities record higher levels of well-being and mental health, prompting renewed interest in the clinical benefits of religion and spiritual practice. ${ }^{6}$

Such talk of resurgence must be tempered, however, by unequivocal evidence of

\footnotetext{
${ }^{4}$ Robin Wright, 'A court overturns a Burkini ban, but not its mindset', New Yorker (August 26),

$<$ http://www.newyorker.com/news/news-desk/a-court-overturns-a-burkini-ban-but-not-its-mindset. $>$ [accessed 14 February 2016].

${ }^{5}$ Steven Kettell, 'Illiberal Secularism? Pro-faith discourse in the United Kingdom', in T. Hjelm, ed, Is God Back? Reconsidering the new visibility of religion (London: Bloomsbury, 2015), pp. 65-76.

${ }^{6}$ Jonathan Rowson, 'Love, Death, Self and Soul', RSA Journal 4 (2014), 48.
} 
drastic decline in the institutional strength of organized Christianity in the West, and especially Western Europe.

[Insert Table here]

Formal affiliation across the mainstream Christian denominations, however it is measured, continues to fall. And even if organized forms of religion hold sway, they are far more deinstitutionalized and fluid due to social media, globalization and changing patterns of membership and affiliation.

Overall, this offers us a picture of the contemporary cultural landscape as characterized by contradictory and unprecedented currents of religious pluralism and diversification, coupled with institutional decline and strong resistance to expressions of religion in public. We are confronted with 'a perfect storm', therefore, of conflicting and contradictory currents, which the recent Commission on Religion and Belief in British Public Life summarized in this way:

- $\quad$ Increase of those identifying as having 'No Religion';

- decline in Christian belief and affiliation;

- $\quad$ increasing diversity amongst those who do claim a religious faith. ${ }^{7}$

In short, what many are describing as the 'post-secular' is when 'the presuppositions of the secularization thesis no longer apply'. ${ }^{8}$ Modernization does not necessarily lead to the effacement of religion; yet by implication, currents of modernization and secularism can and do co-exist with continuing attachment to traditional, religiously-

\footnotetext{
${ }^{7}$ Commission on Religion and Belief in British Public Life, Living with Difference: Community, Diversity and the Common Good (Cambridge: Woolf Institute, 2015), p. 7.

${ }^{8}$ Lieven Boeve, 'Religious education in a post-secular and post-Christian context', Journal of Beliefs \& Values, $33: 2$ (2012), 143-56 at 145.
} 
derived, forms of belief and identity. Rather than being the inexorable outcome of unilinear social change, secularism comes to be seen as but one option amongst 'multiple modernities'. 9 This unprecedented co-existence of the sacred and the secular is why I don't think of our current situation as merely a religious revival, but as something quite novel and distinct. It is clear that against many expectations, religion has not vanished from Western culture. If anything, it exercises a greater fascination than ever before.

\section{Return of Religion to the Public Square}

This characteristic of the simultaneous and problematic co-existence of religion in the public square creates, in turn, a highly ambivalent, even agonistic, climate for policymakers. I want now to touch briefly on three examples: how religion confounds the boundaries of local, national, global; how religion injects the language of value into public discourse; and how religious identity is being incorporated into existing equality and diversity frameworks.

\subsection{Local, National, Global Expressions of Religion: a Case of Divided Loyalties?}

One of the distinctive contributions that faith-based organizations make to the public square is their ability to draw together levels of local, national and international mobilization. They are, perhaps uniquely, genuinely transnational organizations. The flows of globalization are of course one of the major factors to have shaped the resurgence of religion, as migrants from the global South-often from former European colonies-have moved into Europe and the United States, bringing vital

\footnotetext{
${ }^{9}$ Shmuel N. Eisenstadt, 'The Reconstruction of Religious Arenas in the Framework of 'Multiple Modernities", Millennium: Journal of International Studies, 29:3 (2000), 591-611.
} 
new expressions of religious belief and practice back into the public square.

Yet, of course, this has been an ambivalent heritage. The rise of political Islam in the Middle East is due in part to the history of economic and political intervention on the part of European states and the United States—but that global drama is also played out at a local level as European and American young Muslims are 'radicalized' by events in Afghanistan, Iraq and Syria and are drawn to take part in armed struggle. Such transnational affinities mean that being a British or French Muslim cannot be defined independent of one's identification with the fate of Muslims in South Asia or the Middle East. National governments are faced with the challenge of how to counter such radicalization through strategies ranging from education to counterterrorism to surveillance. In the face of transnational religious loyalties, allegiance to the modern, territorial nation-state comes under threat.

And whilst there are several mitigating factors behind those divisions, a perception on the part of many Muslims that one of the things that distinguishes them from the West is a way of life that is fundamentally religious, is clearly primary. It also highlights, in passing, the fact that Europe (to a lesser extent North America) may always have been a secularizing 'exception' to an otherwise mainly religious world. But the influence of globalization - both in the way in which immigration has engendered a new generation of cultural diversity, and in the way international tensions between the

superpowers shape the political sympathies of a religious diaspora-'brings that home' very starkly. Such is the postcolonial, 'glocal' nature of religious identity and affiliation in a post-secular society.

\subsection{Religious and Spiritual Capital}

Secondly, much of the research into the new visibility of religion over the past 
generation focuses on how religious organizations are especially adept at mobilizing networks of activism and association, with beneficial effects for local civil society. Yet it is clear that such faith-based activism combines the material dimensions of social, economic and human capital with other resources of metaphysical beliefs, ethics and attitudes.

In their review of the literature around the debate about social capital and religion, Chris Baker and Jonathan Miles-Watson draw a distinction between religious and spiritual capital. Religious capital denotes the 'what' of faith-based contributions, or 'the concrete and tangible actions and resources that faith groups contribute to civil society', whereas spiritual capital refers to the "why", or: 'that area of belief or faith that actually energizes or motivates our ethical and public living'. ${ }^{10}$ The former denotes the material aspects of social capital; but the latter refers to the metaphysical dimensions of faith-based contribution.

Baker and Miles-Watson argue that in reality the two cannot be separated, since spiritual capital 'energises religious capital by providing a theological identity and worshipping tradition, but also a value system, moral vision and a basis of faith'. ${ }^{11}$ Other commentators have spoken of 'faithful capital' as a kind of synthesis of the 'what' of the religious and the 'why' of the spiritual, whereby sets of distinguishing practices such as 'local rootedness', 'acceptance of failure', 'genuine participation and working together' are undergirded by language and values such as 'love', 'hope', 'judgement', 'forgiveness', 'remembrance' and 'hospitality'. ${ }^{12}$

So we must consider not just how religious agents re-emerge into public policy as

\footnotetext{
${ }^{10}$ Chris Baker and Jonathan Miles-Watson, Faith and Traditional Capitals: Defining the Public Scope of Spiritual and Religious Capital. Implicit Religion (e-book: 2010), pp. 17-69.

${ }^{11}$ Ibid., p. 33.

${ }^{12}$ Archbishops' Commission for Urban Life and Faith, Faithful Cities: A call for celebration, vision and justice (London: Church House Publishing, 2006), p. 3.
} 
welcome sources of social capital and human resources, but also how their renewed visibility requires the discourse of public life to accommodate the 'why' of metaphysical alongside the 'what' of their material resources; and this is at the heart, perhaps, of the post-secular dilemma. We may like the prospect of an attenuated public square finding new sites of voluntary labour and activism; we may warm to the idea that religion can revitalize the tired conventions of public morality; but on the other hand, we worry whether or not the conventions of liberal democratic polity can survive the incursion of partisan, religious beliefs and values that often appear to belong to a bygone and oppressive age.

\subsection{Religious Identity Politics}

A third area has been the way in which religious identity has demanded to be reincorporated back into the vocabulary and repertoire of equality and diversity policies. Tariq Modood calls this the manifestation of 'Ethno-Religious Assertiveness'. The new visibility of religion complexifies liberal democratic notions of equality and diversity, formerly conceived along lines of race and ethnicity but not religion (because that was assumed to be epiphenomenal). Modood terms this dominant mode of discrimination 'colour-racism', reflecting predominantly secularist legislation and policy that was 'tone deaf' to religion. ${ }^{13}$

Since the 1950s, UK and European law has seen the gradual introduction of significant legislation to guard against discrimination in employment, provision of services, education and other human rights, making it illegal to discriminate against someone on grounds of gender, race, sexual orientation, disability and marital status.

\footnotetext{
${ }^{13}$ Tariq Modood, 'Ethno-religious assertiveness out of racial equality', in D. Llewellyn and S. Sharma, Religion, Equalities and Inequalities (London: Routledge, 2016), p. 38.
} 
In more recent years it has also been unlawful to discriminate against workers because of their religion or belief, or lack of religion or belief, either through direct or indirect discrimination, harassment or victimization. So in the UK the Employment Equality (Religion or Belief) Regulations of 2003 and the Equality Acts of 2006 and 2010 extended those principles of basic protection against discrimination to questions of 'religion and belief'. What is called 'reasonable accommodation' must be made in respect of employees' observance of religious dress, holidays, diet and provision of prayer space at work.

But introduction of faith into existing legislation has also been problematic when traditional values of faith come into conflict with more progressive assumptions of secular liberalism. If we think of basic human rights in relation to the burkini ban which 'human right' trumps the other? The post-Enlightenment prohibition on the public display of religious symbolism or affiliation meets the expression of an emergent European Muslim identity which does not conform to this particular configuration of public neutrality and private profession. Is it significant, also, that this particular religious version of the 'culture wars' is inscribed on the bodies of women?

Another of the unintended consequences of this legislation has been the emergence of a particular class of legal cases, which concern Christians who evoke this legislation in support of claims that for whatever reason they have experienced discrimination on the grounds of being Christian at work. Often, this concerns instances where an individual has been disciplined or even dismissed for expressing views and opinions that have been held to contravene other clauses in the same Equalities and Diversity Acts. So Evangelical Christians with conservative views on same-sex marriage, or LGBTI rights, for example, who have expressed those views in the workplace have found themselves disciplined; and have taken their cases to 
law citing freedom of religion. It leaves us with a tension between equality premised on liberal models of a neutral, non-partisan, agnostic public realm, and sensitivity towards public displays of religious conviction. Policy-makers are caught between the seemingly incommensurable hierarchies of equality, and are left struggling on how to adjudicate between rival sensibilities around religion.

Whatever the rights and wrongs of these individual cases, it seems to me they expose a deep dis-ease about the nature of religious faith in our society and to reveal to a large extent a deficit of what we might call 'religious literacy': basic information about religion-its values and obligations-as well as lack of first-hand experience of what it means to be a person of faith. It leaves us with huge unanswered questions about the basis on which religion is mediated into the public square; the extent to which religious belief and conviction is 'normalized' or not within a functionally secular society; and how the ambivalent legacy of religion as both source of social cohesion and conflict can be acknowledged and managed.

\section{Reflexivity and Rapprochement}

\subsection{Religious Literacy}

Such a unique and unprecedented combination of resurgent religion and persistent and implacable secularism is one of the reasons for the emergence of debates about religious literacy. There is need for greater understanding of and knowledge about religion, in all aspects of public life.

The term first came to prominence with the publication of Stephen Prothero's book Religious Literacy in 2001. Prothero's work is especially interesting given the theme of this journal issue, since his core thesis is that even though the separation of 
Church and State in the United States-and therefore the prohibition on teaching religion in public schools -is enshrined in American public policy, levels of basic knowledge of religion are so low that people are incapable of understanding the nuances of much that goes on around them. ${ }^{14}$

Not only are people ill-equipped to understand the impact of religion on world affairs, says Prothero, but they are lamentably ignorant of the religious roots of their own cultural heritage as well as those of their neighbours. It breeds a kind of parochialism, an inability to appreciate pluralism, and it breeds a kind of 'forgetting' of the religious narratives, values and symbols that, however attenuated, still inform our political and cultural life today.

So basic knowledge of religious traditions is important not just at a personal level but as a basic matter of cultural literacy. In order to be truly educated, argues Prothero, we need to aspire to a level of religious literacy. It is a pre-requisite of responsible and effective citizenship. We cannot make good political judgements without it; and once more, that is something that extends across the spheres of local, national and international politics. In the case of the US, for example, religious literacy might enable greater understanding of the beliefs of one's next-door neighbour, or how faith informs presidential campaigns, or how religion shapes global conflicts.

This is more than rote learning of facts. It extends to knowing the power of narrative to shape religious identity. 'It is the ability to participate in our ongoing conversation about the private and public powers of religions. ${ }^{, 15}$ As a result, Prothero concludescontroversially - that whilst faith communities have a responsibility to cultivate wider public awareness, religious literacy should also feature on the curriculum of public

\footnotetext{
${ }^{14}$ Stephen Prothero, Religious Literacy: What Every American Needs to Know-and Doesn't. (San Francisco: Harper \& Row, 2007).

${ }^{15}$ Ibid., p. 18.
} 
schools and higher education. ${ }^{16}$ He concedes that this may be regarded as a departure from the Constitutional separation of Church and State; but he responds by making a distinction between the teaching of religion and teaching about religion. ${ }^{17}$

This approach affirms the following tenets as conditioning and framing religious literacy:

(a) All religions are diverse;

(b) religions evolve and change;

(c) religious influences are embedded in all aspects of human experience and culture. $^{18}$

So religion is not something that can be reified or essentialized: all knowledge claims (including religious ones) are socially constructed and represent particular 'situated' perspectives. Is it even possible, I wonder, to say that such-and-such a religion is a religion of peace (or violence) or that it teaches ' $x$ ' truth or proposition? It is all about context and about the lived expression of faith in a particular place and time. So the question then becomes whether actually the best preparation for religious literacy is that of encounter with lived expressions of faith in all their complexity: an emphasis on the phenomenological rather than the doctrinal.

\subsection{Post-secular Rapprochement}

A second example of a greater reflexivity of faith, enacted in pursuit of specific common goals leads on from this spirit, of public engagement with religion as contextual, providing understanding of it as thoroughly embedded in culture and

\footnotetext{
${ }^{16}$ Ibid. p. 21.

${ }^{17}$ Ibid. p. 161.

${ }^{18}$ See Diane L. Moore, 'Religious Literacy in the context of Theology and Religious Studies', in A. Dinham and M. Francis, eds, Religious Literacy in Policy and Practice (Bristol, UK: Policy Press, 2016), pp. 39-54.
} 
being able to witness it in action. Studies are emerging now of forms of post-secular engagement in the public square that are inclusive and collaborative and yet do not conform to the original Rawlsian model of 'bracketing out' the particularities of transcendent truth-claims or religious language. Instead, the space of common endeavour becomes the place in which such world-views are mediated, not into a single language but into pragmatic common cause in which pluralist traditions cohabit.

Such pragmatic collaborations across different faiths and philosophies represent what the urban geographers Justin Beaumont and Paul Cloke call 'postsecular rapprochement'-partnerships forged from the 'interconnections between religious, humanist and secularist positionalities in the dynamic geographies of the city'. ${ }^{19}$ They are embodied in community initiatives such as food banks, youth training centres, mental health projects and asylum campaigns that demand a collective political and ethical response. Such shared responses to social or economic need give rise to meaningful dialogue about the well-springs of participants' motivations-what Baker and Miles-Watson term their 'spiritual capital' ${ }^{20}$ - to transform things for the better.

Luke Bretherton relates the story of a meeting of London Citizens, a broad-based community organizing network, which for him exemplifies the new order in which 'different language [and religious] worlds stand side by side, sometime [sic] collide and sometimes overlap. ${ }^{21}$ He writes about an event featuring a public lecture by a 'secular Jew', Michael Sandel, held in an East London mosque, whose management has fought off claims of international links to al-Qaeda, which draws an audience of

\footnotetext{
${ }^{19}$ Paul Cloke and Justin Beaumont, 'Introduction to the Study of Faith-Based Organizations and Exclusion in European Cities', in Paul Cloke and Justin Beaumont, eds, Faith-Based Organizations and Exclusion in European Cities (London: Policy Press, 2012), pp. 1-36 at p. 32.

${ }^{20}$ Baker and Miles-Watson, Faith and Traditional Capitals.

${ }^{21}$ Luke Bretherton, Resurrecting Democracy: Faith, Citizenship, and the Politics of a Common Life. (Cambridge: Cambridge University Press, 2014), p. 83.
} 
trade unionists, party activists and religious leaders. Political and religious differences are not air-brushed away, but nor is such a gathering framed in terms of short-term political gains or single-issue campaigns, even though citizens' organizing normally does have such a focus. Instead, many different value systems and 'discursive frameworks' are 'collated' into a shared conversation about 'what it means to pursue justice (however conceived) where you live and alongside those who live beside you. $^{22}$ So rather than attachment to specific religious identity and practice of citizenship being mutually exclusive, they nurture one another in dialogue with religious and cultural 'others' whose difference is mitigated by being drawn into common cause in pursuit of local solidarity and where the repository of social capital embraces both the 'why' and the 'how'. Faith-based activism does not have to surrender its distinctive moral or theological world-view in order to participate in the public realm. So there is always a tangible set of goals and a manageable political or civic space within which that is happening; but it is prepared to acknowledge that all faith-based action is also political or has political implications, so refuses to draw a strict distinction between 'religious' and 'public' life-or between the realms of discipleship and citizenship.

For communities of faith, this highlights both 'the difficulty and the importance of prioritizing participative listening and collaborative interpretation over any form of unitary dogmatism [...] of activating the creative potential of normative fallibility, and of engaging the vital spaces between as well as within traditions and communities. ${ }^{23}$ These are the hallmarks of a 'pragmatic public theology' that is performative more than it is propositional and contextual more than it is dogmatic. Whilst it engages with

\footnotetext{
${ }^{22}$ Ibid., p. 86.

${ }^{23}$ Michael S. Hogue, 'After the Secular: Toward a Pragmatic Public Theology', Journal of the American Academy of Religion, 78:2 (2010), 346-374 at 348.
} 
pluralism it recognizes its own rootedness in particular traditions and vantage-points, but seeks to mediate those into public debate.

Despite theological and ideological differences which would appear to militate against any kind of moral or political affinity, the challenges of geographical proximity present opportunities for negotiated, provisional but nevertheless genuine collaboration. By basing civic engagement on what matters to stakeholders in a local community, the purpose of such post-secular rapprochement is not to impose a single metaphysical dogma but to nurture constructive alliances around shared moral tasks. It has proved remarkably successful in building respectful relationships based on reciprocal and public dialogue that bear fruit in the shape of sustainable local politics.

\section{Conclusion}

The post-secular is about combining a greater reflexivity towards the claims of secularization with a greater self-consciousness towards the choices informing one's own religious convictions. It is about 'learning to appreciate what [a] faith can mean for people of today' ${ }^{24}$-how it offers meaning, how it constructs a credible 'actionguiding world-view', how it contributes to the common good. I argue therefore for the cultivation of public spaces of exchange and shared action which demonstrate how religion works for people in particular situations, in practice. It shows how immersion in a tradition might foster virtue and character which, contrary to the expectations of many, embodies a powerful and sustainable bond between the practice of faith and the exercise of citizenship.

In such a model, shared territory and common interest in 'the common good'-as a concrete practice, not an abstract concept-serve as catalysts for the creation of

\footnotetext{
${ }^{24}$ Prothero, Religious Literacy, p. 151.
} 
spaces of hospitality in which everyone is invited to tell their stories, offer their testimonies, of their own particular vision of justice and flourishing-but most fundamentally, how that is nurtured by the well-springs of faith. And actually, that process begins with a perennial (and for some, a sacred) question: Who is my neighbour? 